\title{
Enhancing the Quality of Foreign Language Learning Through Extracurricular Programs for Vietnamese Students
}

\author{
Chau Tuong Nguyen (Corresponding author) \\ University of Economics and Law, Vietnam National University - Ho Chi Minh City \\ Quarter 3, Linh Xuan Ward, Thu Duc Dist., Ho Chi Minh City, Vietnam
}

Tel: 849-8306-0390Ｅ-mail: tuongchauhp@gmail.com

\author{
Received: June 3, 2019 Accepted: June 24, 2018 Published: June 26, 2018 \\ doi:10.5296/elr.v5i2.14980ＵRL: https://doi.org/10.5296/elr.v5i2.14980
}

\begin{abstract}
The study of 'Enhancing the quality of foreign language learning through extracurricular programs for students' was conducted in Ho Chi Minh City Vietnam National University (VNU-HCM) from May to August of 2015. The research objectives are to explore students' needs of English extracurricular activities and evaluate the feasibility of certain extracurricular activities, from which propose appropriate English extracurricular programs for students. The study applied qualitative and quantitative methods, using questionnaires to survey the students' needs of English extracurricular activities and interviews with university leaders on practical experience in implementing extracurricular programs. There were 3000 of 8000 students living in VNU-HCM dormitory B participated in the survey, representing $37 \%$. The research results showed that: the objective of joining in English extracurricular activities was to develop English communicative skills with the highest agreement rate of nearly $90 \%$, followed by that of improving academic English and professional English that gained $80 \%$ of agreement. In addition, considering only the question received more than $60 \%$ of agreement, the degree of participation in extracurricular activities was different according to each objective. For English extracurricular activities focusing on academic English, the form of short-term training was selected most, about $70 \%$ of agreement, and the other forms such as Eloquence and Writing Composition were agreed about 60\%. For enhancing professional English, the forms of Company Tour and Exhibition Fair had the participation rate reaching over $80 \%$, followed by Workshop with the rate of $70 \%$. For improving English communicative skills, the results showed that: the favourable activities received over $80 \%$ of agreement consisting of watching movies, listening to music, tourism and speaking clubs;
\end{abstract}




\section{MInstitute Macrothink $_{\text {Int }}$}

Those were agreed by $60-70 \%$ of students included: gameshow, art festival, book cafe, puzzle, karaoke, lunch hour; And the less attractive forms with under $60 \%$ of agreement were sports, dramas and songs writing in English.

Keywords: Quality of foreign language, Extracurricular programs, Student

\section{Introduction}

From many research results, classroom-based language education tends not to meet learners' linguistic, cognitive and affective needs (Benson, 2011; Lamb, 2007; Richards, 2015). The recruiters' frustration with graduates' English competence has been easily seen from many media channels (Hoang, 2008; Pham \& Nguyen, 2012, Vu, 2007). There is also a common fact in Vietnam that most of universities annually face to the unequal English entry level of first-year students and a shortage of foreign language training hours allocated in the bachelor training programs. As a result, the qualities of English training at universities are often not highly respected by learners and employers. It leads to an urgent need of improving the quality of English teaching and learning at universities. Therefore, Ministry of Education and Training (MOET) national foreign languages project 2020 has been extended to 2025 to continue on supporting English training reforms, in which the value of out-of-class learning is hightlighted. On the basic, the supplement of English extra-curricular activities to the mainstream English training programs is now considered as one of the most essential solutions for enhancing the quality of English training at Vietnamese universities. With the flexibility of English extracurricular activities, students will have many opportunities to practice English after the class, increase their passion on English as well as improve their foreign language self-study skill. Currently, some Vietnamese universities in Ho Chi Minh city center have developed very successfully English extracurricular programs for students, namely Ho Chi Minh City (HCMC) Polytechnic University and HCMC Foreign Trade University, with many interesting and useful English contests and gameshows. However, in Thu Duc district, especially in Ho Chi Minh City Vietnam National University (VNU-HCM) Dormitory B with a capacity for over about 8.000 students, there are still lack of effective English extracurricular programs.

Extracurricular activities have two basic characteristics: (1) not in the mainstream program, (2) designed to serve a specific goal, not only towards social issues (Holland \& Andre, 1987). Due to being out of the mainstream program, extra-curricular activities are often not compulsory, therefore they should be built up according to the mechanism of encouraging, rewarding, and propagating the practical benefits of contributing activities, raising self-awareness on constantly learning and personal development. And there are two types of extracurricular activities: formal/structured and less formal/unstructured. The informal extracurricular activities emphasize on leisure and entertainment activities, for example: watching television and films. In contrast, the formal extracurricular activities require content structure, interaction of participants, like volleyball competition and cultural contest. According to research by Marsh and Kleitman (2002), content-oriented extracurricular activities will have a more positive impact on human development, especially academic achievement. Extracurricular activities are considered an indispensable part in the modern 
education program, developing the human comprehensively from reasoning to practicing activities, from knowledge in the school to experiment in the society. When participating in extracurricular activities, people can learn to practice communication skills, teamwork skills, problem solving, strategic planning, developing logical thinking, recognizing inner strength in one's own, raising awareness of community concern, being responsible and socially useful. In addition, English extracurricular activities help reinforce the knowledge and skills taught in the main curriculum, providing practical communication environment to make English teaching and learning more vivid, achieving the higher efficiency of English training at universities. Organizing effective English extracurricular activities aims to create a healthy academic playground, improving faster students' language skills as well as enriching their spiritual life.

The study on 'Enhancing the quality of foreign language learning through extracurricular programs for students' aims to develop practical English extra-curricular programs for students, contributing to improve the quality of English training at universities as well as creating a useful academic playground for students living in the dormitory.

1) Exploring students' needs of extracurricular activities for language learning and practice.

2) Evaluating the feasibility of certain extracurricular activities.

3) Developing appropriate extracurricular programs

\section{Methods}

The study applied qualitative and quantitative methods, using SPSS software to analyze the data and present the study results in descriptive statistics. The data was collected from questionnaires for students on their needs of participation in English extracurricular activities and interviews for university leaders on their practical experience in organizing English extracurricular programs. The questionnaire was designed with 26 items and two main sections: Section 1 (3 items) exploring students' objectives of participating in English extracurricular activities; Section 2 (23 items) looking for learners' interests in a certain types of extracurricular activities, such as short-term training, specialized training, internship, commentary writing, seminar, eloquence, contest, cultural festival, exhibition fair, watching movie, listening to music, karaoke, teambuilding, gameshow, song writing and performance, art performance, drama, gala, citytour, travelling, book cafe, puzzle, lunch hour, and sport. Section 2 has 3 sub-sections: the activities meeting the demand for improving test taking strategies in international language exams (4 items); The activities for enhancing ESP competence ( 3 items); And the activities aiming at developing English communicative skills (16 items). The questionnaire was randomly delivered to all students in the dormitory for a direct completion within 20 minutes, during 03 months from May to August in 2015. There were 3000 of 8000 students living in VNU-HCM dormitory B participated in the survey, representing $37 \%$. 


\section{Macrothink

\section{Results}

\subsection{Objectives of Extracurricular Activities}

\subsubsection{Improving English for International Examination}

There were $78.9 \%$ of respondents confirming their goal of joining in English extracurricular activities to achieve an international English certificate. One of the prerequisites for graduating from the university or studying overseas.

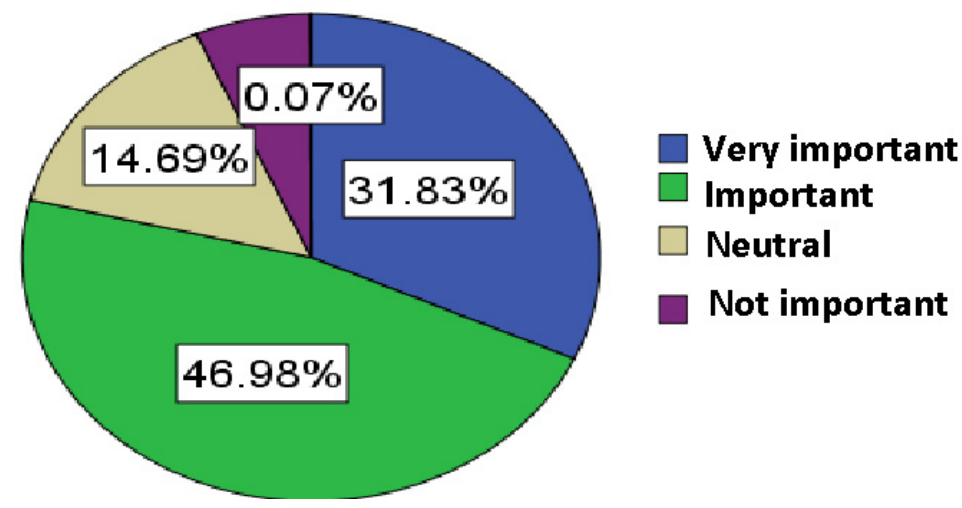

Figure 1. Improving English for international examination

\subsubsection{Improving English for Special Purposes (ESP)}

Due to the percentage of students of the University of Economics - Law accounting for 50\% of the total number of students participating in the survey, the need of ESP improvement was presented with a relatively high rate of $82.3 \%$. It was suggested to mention on business English or legal English, combining with the participation of relevant real companies.

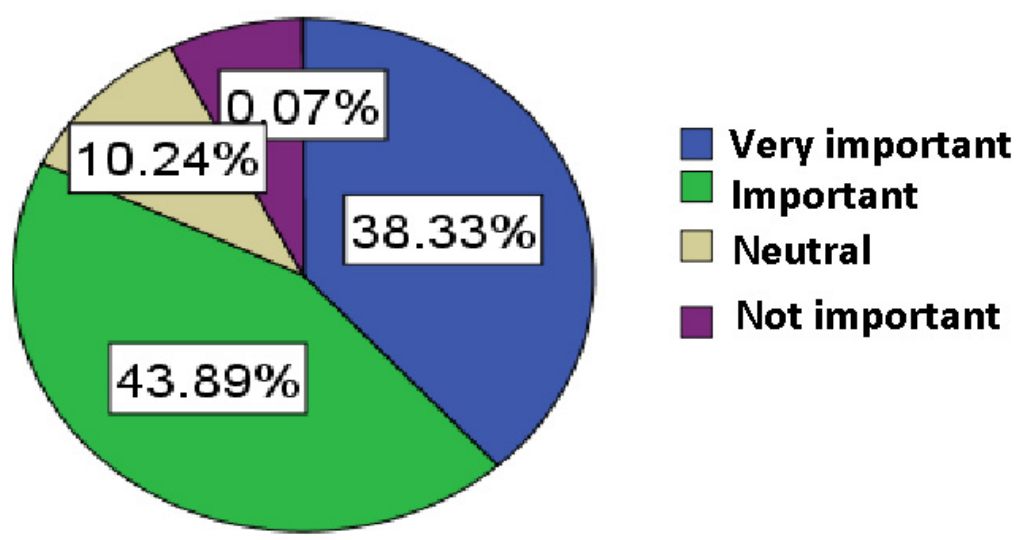

Figure 2. Improving English for special purposes 


\section{Macrothink \\ Education and Linguistics Research \\ ISSN 2377-1356 2019, Vol. 5, No. 2}

\subsubsection{Improving Daily English Communication}

For students, daily English communication was their most favourable goal of English learning with the rate of $88.3 \%$. It emphasized on neccessary fundamental language knowledge and skills before advanced English such as academic English or English for Special Purposes. Therefore, English communication was easy to get attention from students in the first two year period of the bachelor training program.

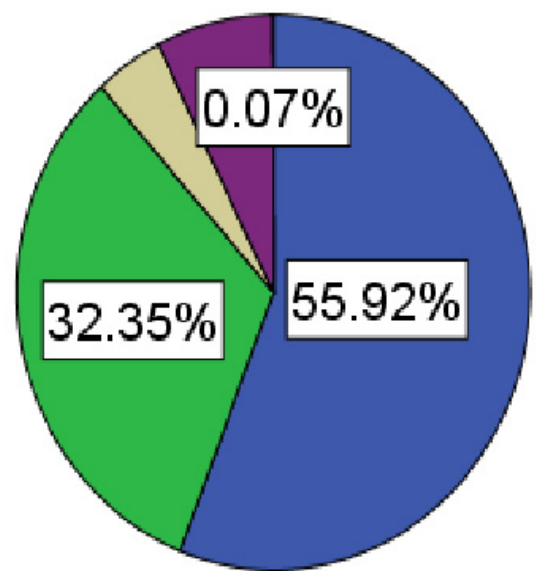

\section{$\square$ Very important \\ Important \\ Neutral \\ Not important}

Figure 3. Improving English for communication

\subsection{The Feasibility of Extracurricular Activities}

3.2.1 Types of English Extracurricular Activities Aiming at Improving English for International Examination

The supplement English extracurricular programs that aimed at improving scores in international English examination required a well-structured training content and sufficient time for skill construction. These can be presented in the types of short-term training, eloquence, and commentary writing. In which, the short-term training received more than $70 \%$ of agreement, followed by eloquence and commentary writing with around $60 \%$.

(1) Short-term training

$71.3 \%$ of respondents agreed to participate in extracurricular activities organized in the form of specialized training with hot topics and well-known presenter/trainer. 


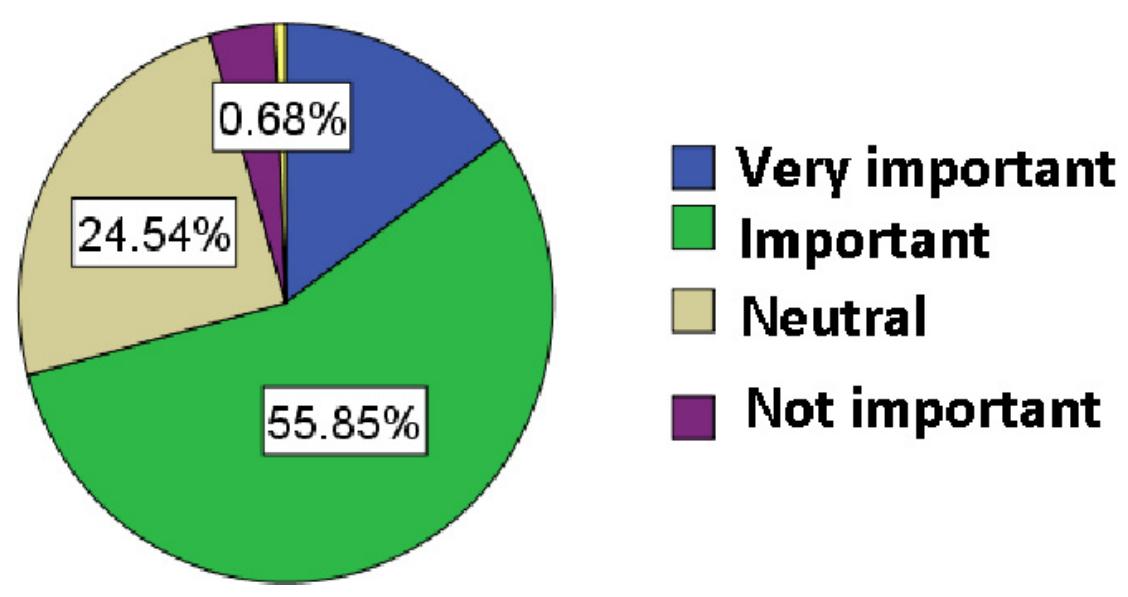

Figure 4. Short-term training

(2) Eloquence

$62.7 \%$ of respondents agreed to participate in extracurricular activities organized in the form of English eloquence which required a careful preparation of English listening and speaking skills as well as life experience for raising personal viewpoints.

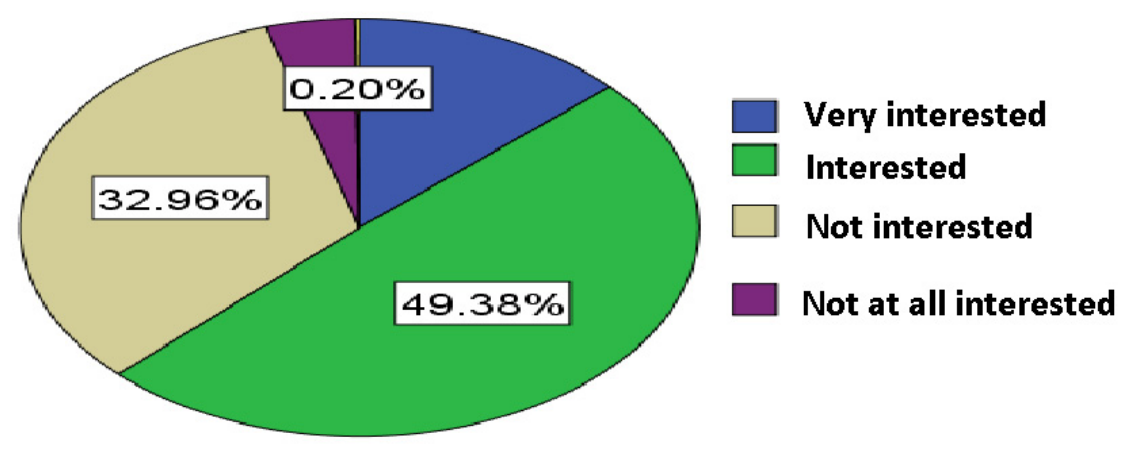

Figure 5. Eloquence

(3) Commentary writing

There were $57 \%$ of respondents who supported to the form of commentary writing to enhance academic English writing skill. This is an indispensable requirement in English tests to assess languge competence following the international standard. 


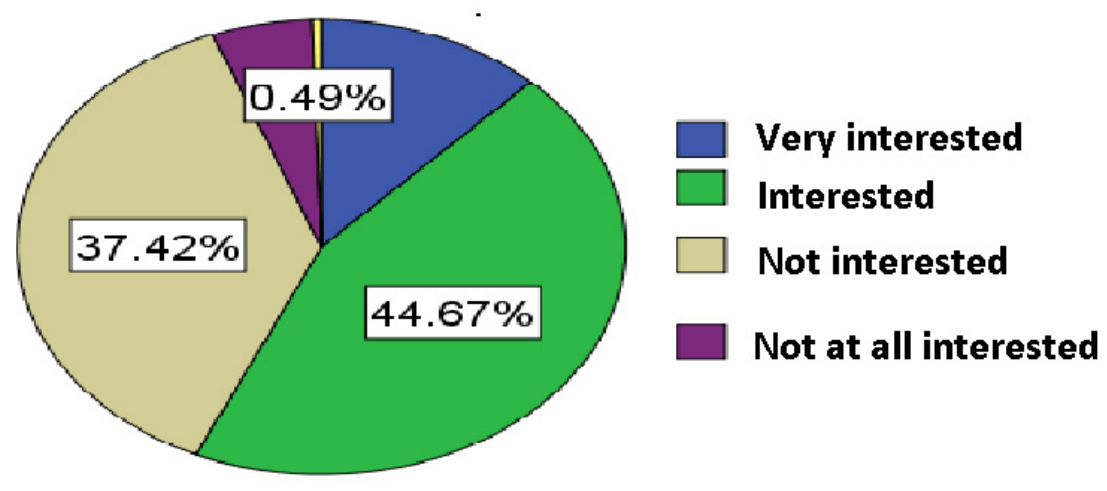

Figure 6. Commentary writing

\subsubsection{Types of Extracurricular Activities Aiming at Improving ESP}

Because of the main foreign language training program at the University of Economics - Law using business English, which mentions some issues in Economics and Law, students are somewhat oriented to improve ESP to achieve high achievement in the mainstream curriculum. These ESP extra-curricular activities can be found in specialized English training at the company, exhibition fairs, and constests on company's activities.

(1) Specialized training

In-site English training is assessed as an effective extracurricular activity with more pracical experiments in English. There were $81.5 \%$ of respondents who agreed to join in extracurricular activities under the form of in-company English training with the popular form of internships.

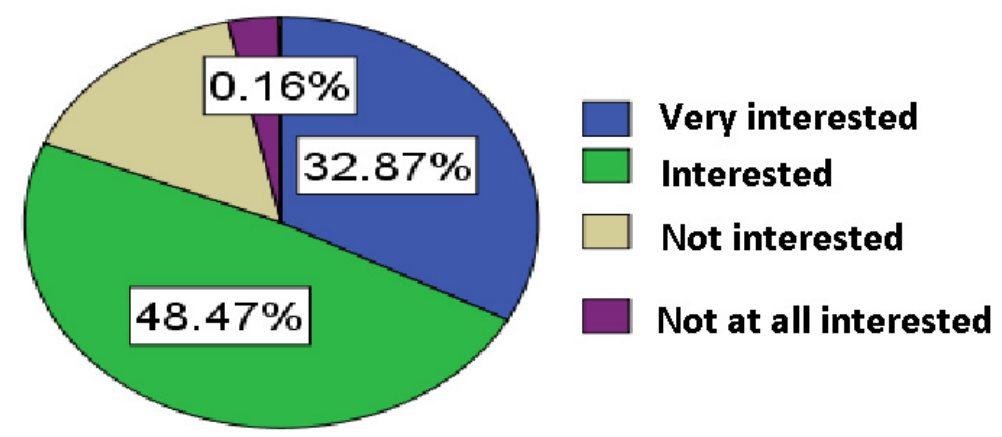

Figure 7. Specialized training

(2) Exhibition fairs

Extracurricular activities are presented in the form of exhibition fair providing with many activities of marketing, sales, and care services. These will create a useful environment for 


\section{Macrothink}

students practicing business English. They received the support of over $80.8 \%$ of students participating in the survey.

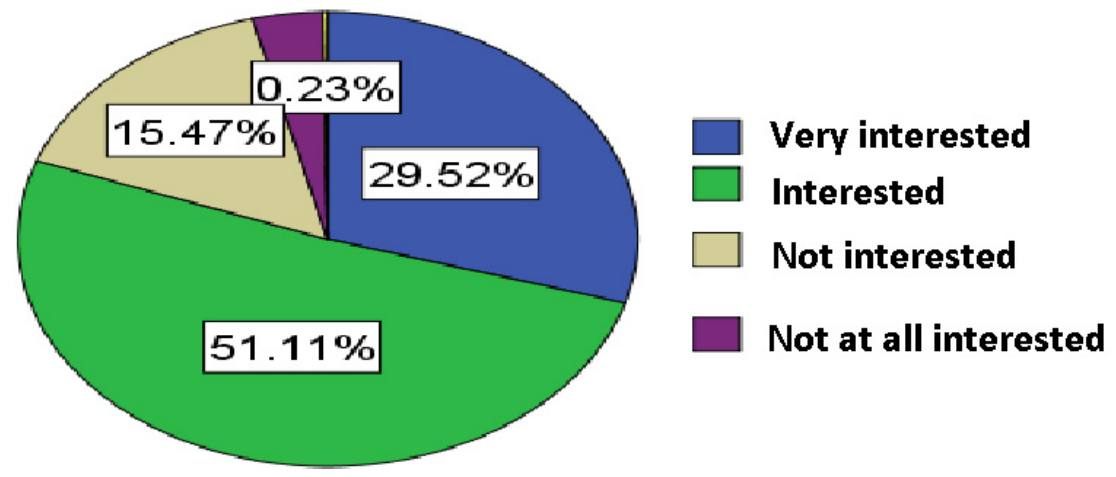

Figure 8. Exhibition fairs

(3) Contests on company's activities

$72.5 \%$ of respondents showed their agreement on extracurricular activities organized in the form of contests, which aimed at exploring the company's business activities. These activities contribute on improving language skills and providing necessary knowledge for students before entering in the real workplace.

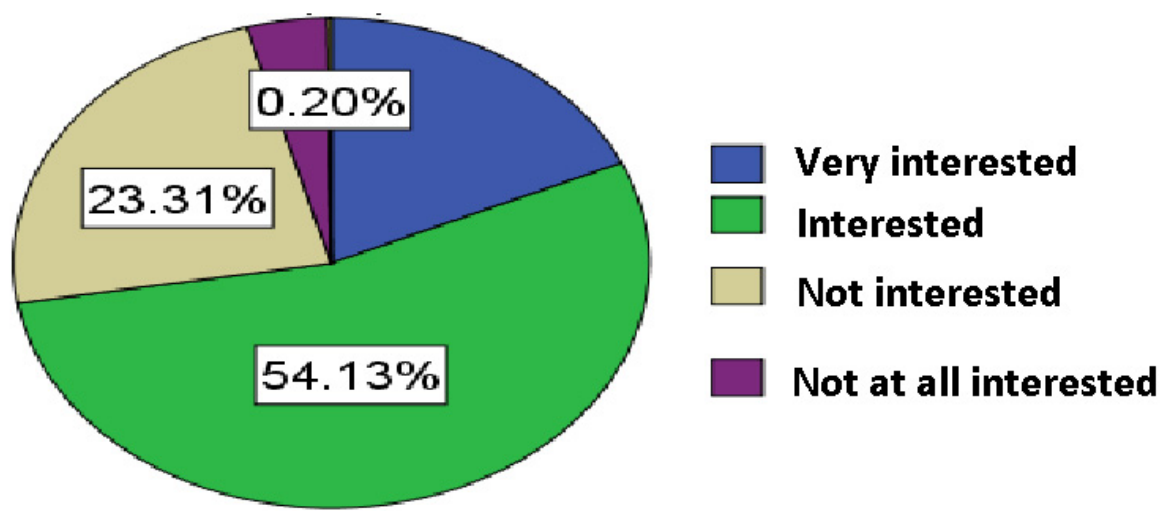

Figure 9. Contests on company’s activities

(4) Professional workshops

Workshops are very useful means for scholars to update the latest information on specialized majors. At seminars, people can learn about knowledge and experience from other speakers and attendees. The workshops need to be scheduled with clear agenda and effective time management. From the survey, $71.6 \%$ of respondents agreed to participate in extracurricular activities organized in the form of seminars or workshops, creating a useful academic 


\section{Macrothink}

environment for students who can share the same interests in some proper topics.

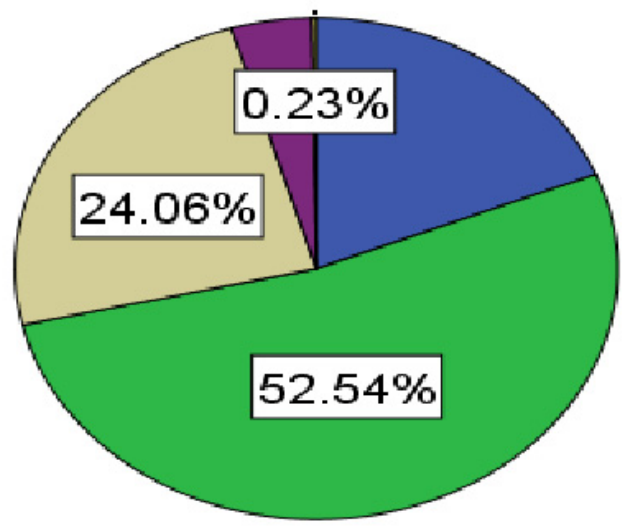

\section{$\square$ Very interested} Interested

\section{Not interested}

Not at all interested

Figure 10. Professional workshops

\subsubsection{Types of extracurricular activities aiming at improving Daily English communication}

Among 16 English extracurricular activities that were designed to improve English communication skills, there were 13 that received over $60 \%$ of respondents ${ }^{6}$ agreement including: (1) Listening to music; (2) Watching movies; (3) City tour; (4) Travelling; (5) Cultural festivals; (6) Outdoor group activity; (7) Speaking club; (8) Game show; (9) Arts performance; (10) Book cafe; (11) Puzzles; (12) Karaoke; (13) Lunch hour. Three activities were considered less attractive to students, receiving less than $60 \%$ of voting, consisting of: (14) Sports; (15) Drama; (16) Song writing and performance.

(1) Listen to music

Listening to English music helps students feel the soul of English by perceiving lyrics and rythms in the most relaxed spirit. Therefore, there was the highest rate voting for this activity, reaching at $89.3 \%$.

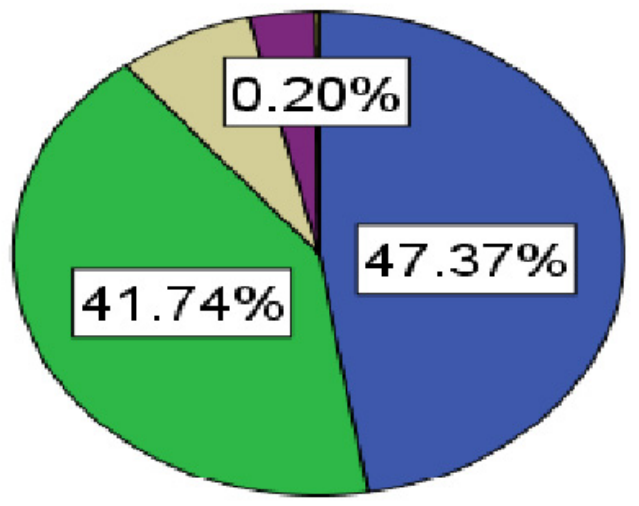

\section{Very interested}

Interested

\section{Not interested}

Not at all interested

Figure 11. Listen to music 


\section{Macrothink}

(2) Watching movies

Extracurricular activities with the laziest nature is watching English films, however language acquisition is not low. This activity was enthusiastically supported by students with the rate of $86.4 \%$.

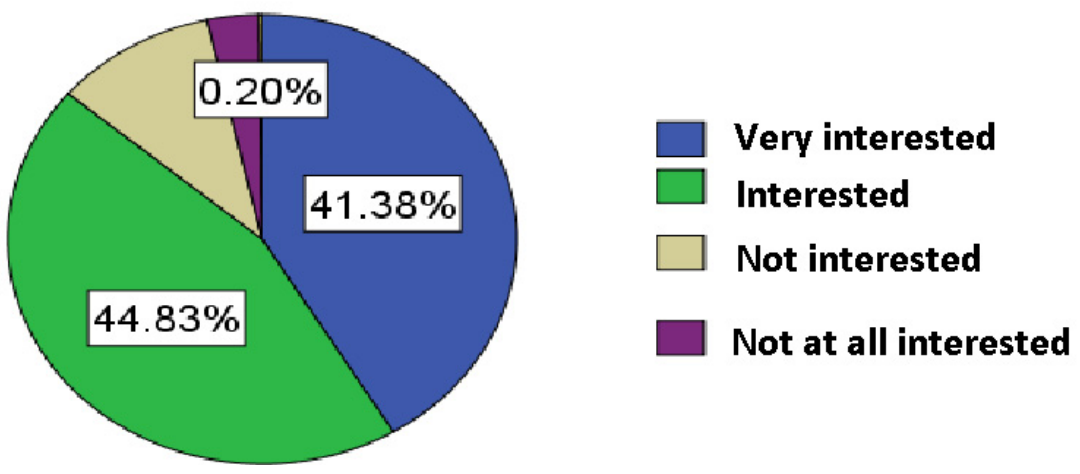

Figure 12. Watching movies

(3) City tours

One of English extracurricular activities having the most practical environmental approach is City tour, for example going to Tây Street in district 1 in HCMC or entering a theme park to communicate with foreigners. These activities also attracted many students with the agreement rate of $84.7 \%$.

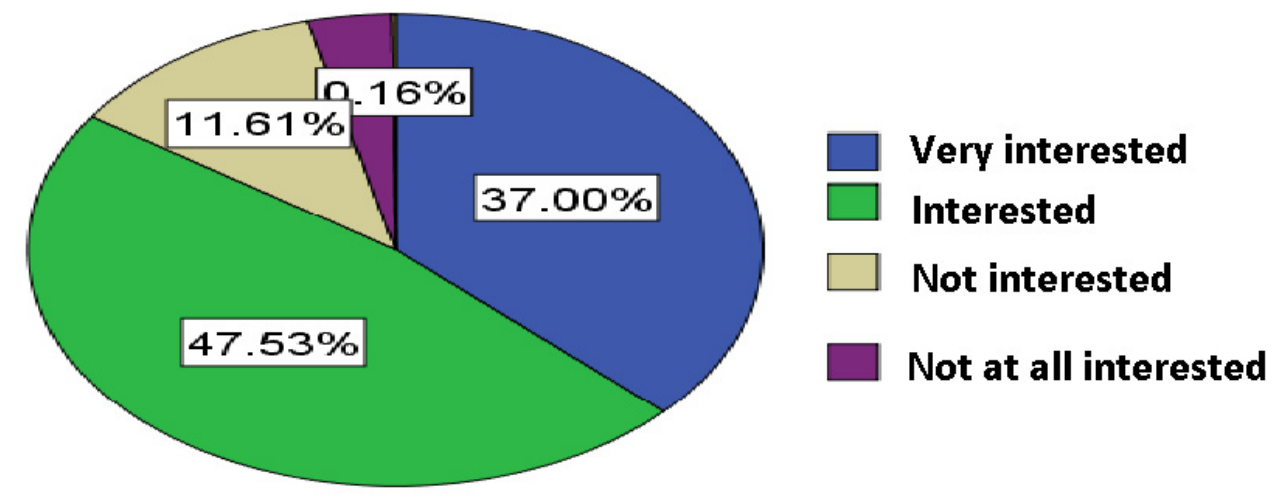

Figure 13. City tour

(4) Travelling

Travelling is the favourable activity of everyone in the society. From the survey, English-based tourism with the aim of improving English communication in a strange and beautiful place was one of the top choices of students, accounting for $83.3 \%$ of repondents. 


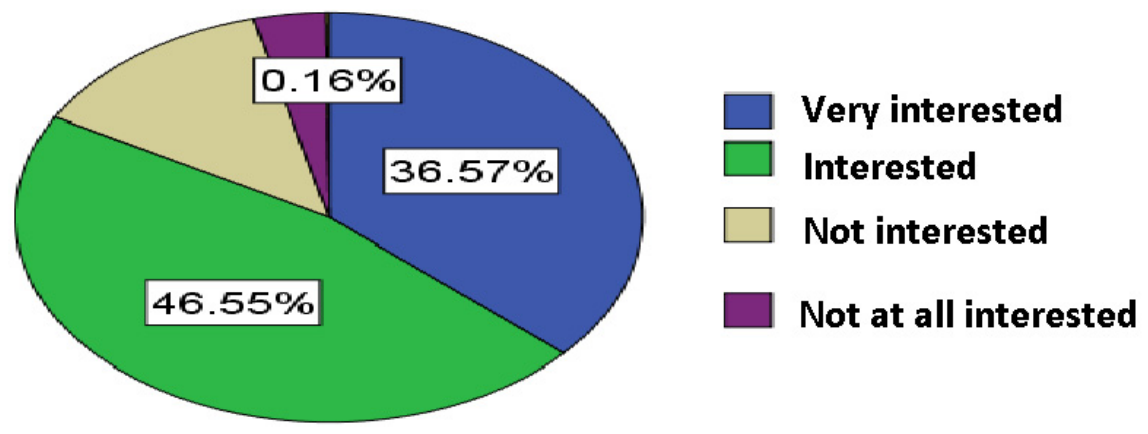

Figure 14. Travelling

(5) Cultural festivals

Extracurricular activities under the form of cultural festivals bring out many interesting performances on clothes, food, music, history, custom, ..., creating an exciting and corlorful English communication environment. These activities received more than $83 \%$ of students ${ }^{6}$ agreement.

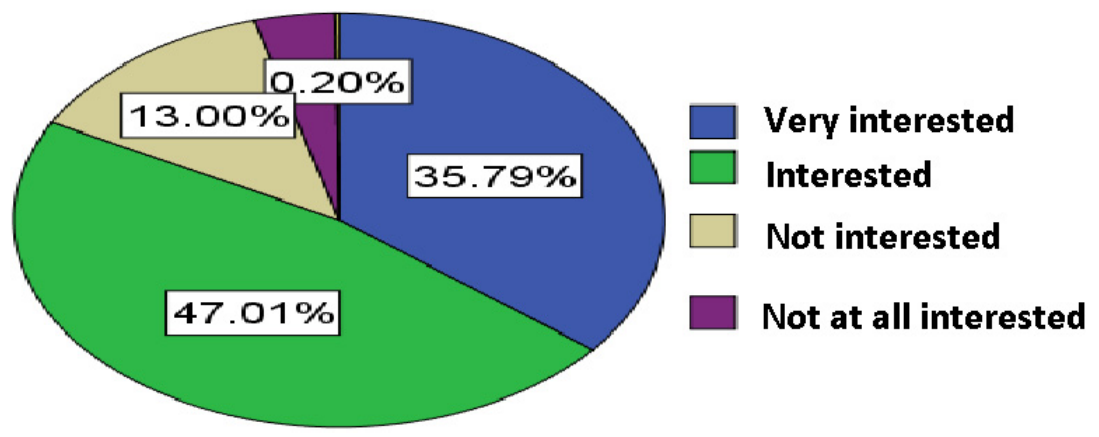

Figure 15. Cultural festivals

(6) Outdoor group activities

Outdoor group activities commonly offer a spacious environment and a larger number of participants, promoting more exciting English communication environment. These activities achieved many students' supports with the agreement rate of $80.9 \%$. 


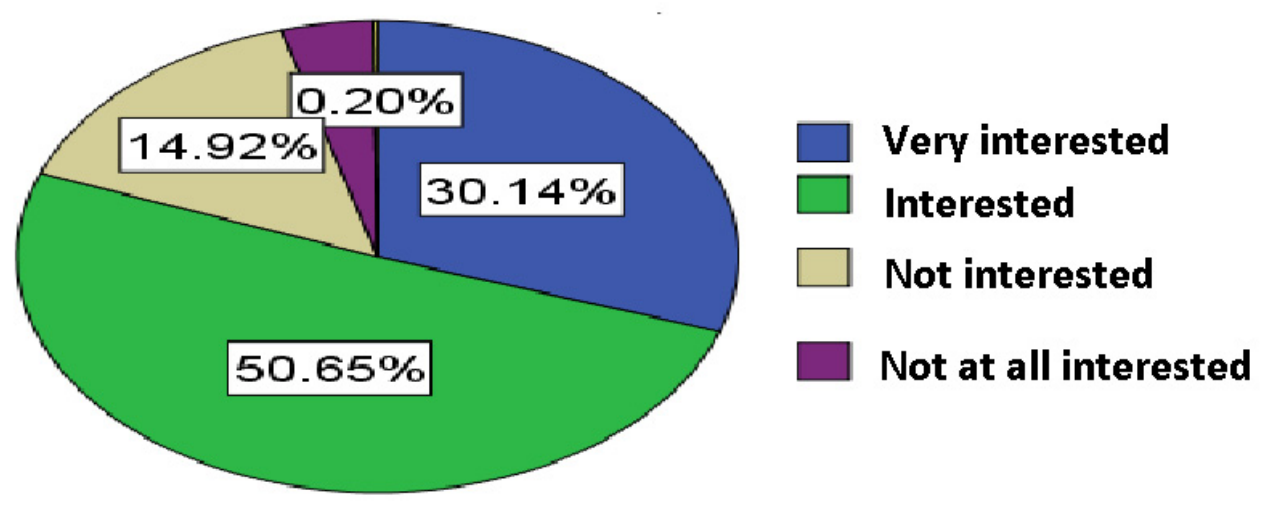

Figure 16. Outdoor group activities

(7) Speaking club

There were $78.6 \%$ of respondents agreed to participate in extracurricular activities organized in the form of English speaking clubs. They expected to have more chances to rexpress themselves in the public where the people would like share their passion in speaking English fluently.

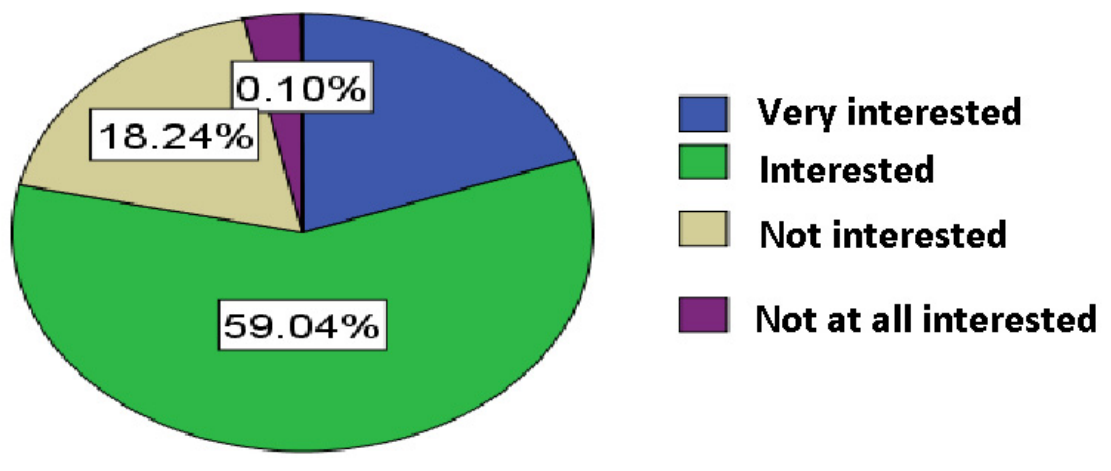

Figure 17. Speaking club

(7) Gameshows

Gameshows in English can be some kind of activity games like warm-up activities or language games such as vocabulary, grammar, four skills. From the survey, the students agreed with the need for gameshows to improve their English level at the rate of $76.3 \%$. 


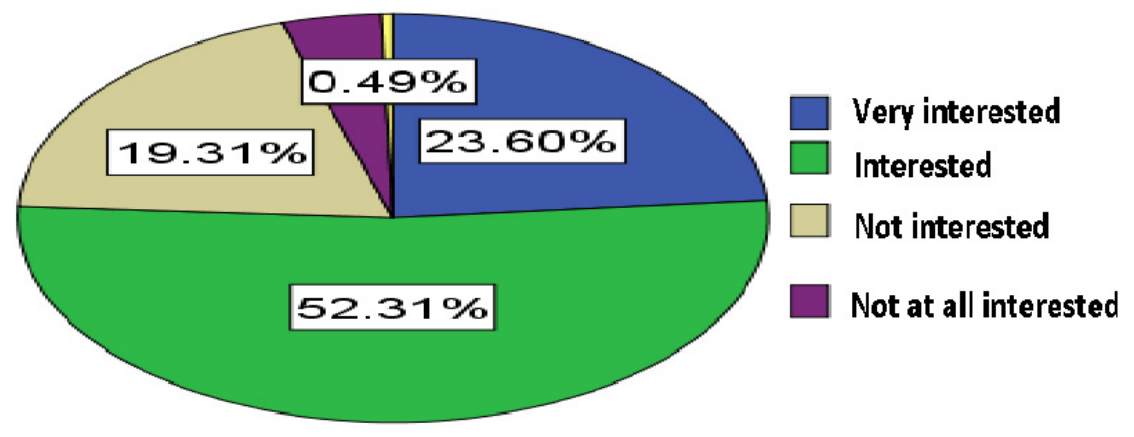

Figure 18. Gameshow

(6) Art performances

English art performances are well-known as English Gala with many intertesting activities including: fashion show, music contest, and English eloquence, specially all presented in in English. This activity received $75.7 \%$ of favor votes.

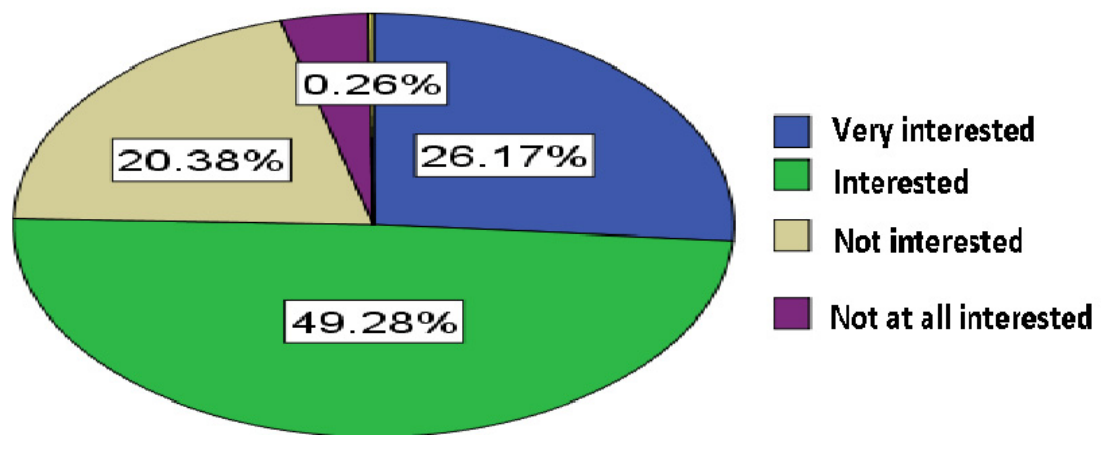

Figure 19. Art performances

(7) Book Cafe

Coffeshop is an ideal space for garthering with nice decorated room, delicious food, and comfortable service. It also satifies customers' need of entertainment and knowledge acquisition. There were more than $69.8 \%$ of students who would like to participate in this type of English extracurricular activity. 


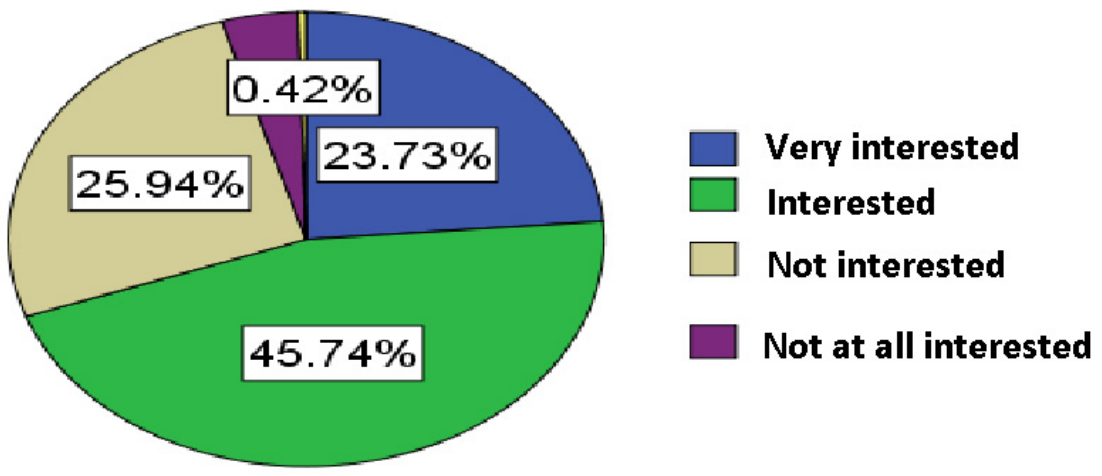

Figure 20. Book Cafe

(8) Puzzles

Puzzles in English are some kind of intellectual games, raising a lot of challenges in brainstorming, discovery and competition. These were also typical characteristics of the youth that caused to reach more than $67.9 \%$ of agreement.

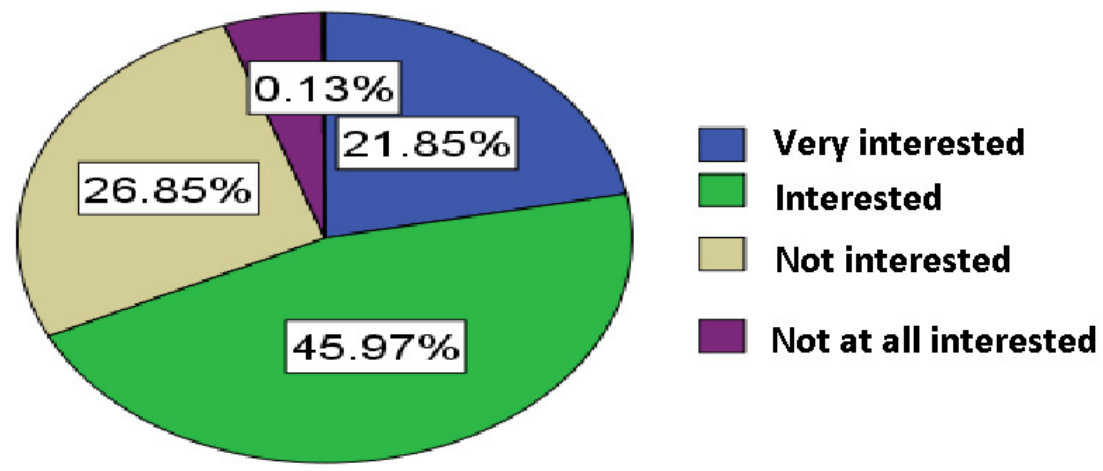

Figure 21. Puzzles

(9) Karaoke

Karaoke in English gained $66.9 \%$ of respondents. This is a very popular relaxing activity for students to release from the stress on studying and living. 


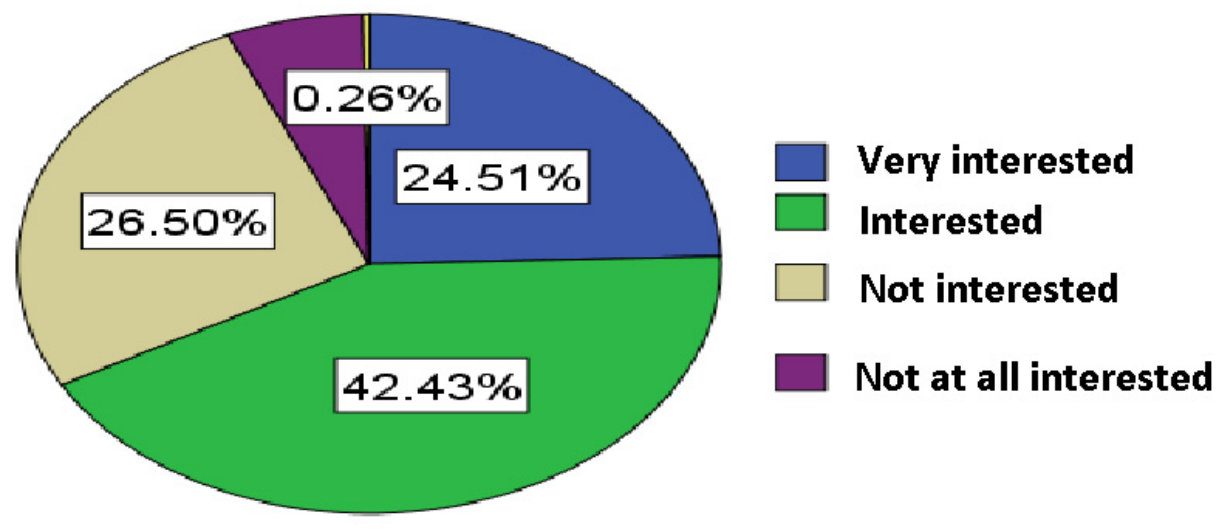

Figure 22. Karaoke

(10) Lunch hour

Taking advantage of every free time for English speaking practice, lunch hour can be set up as a friendly English communicative environment which needs to have foreigners participated. This activity received the support from $59.8 \%$ of students.

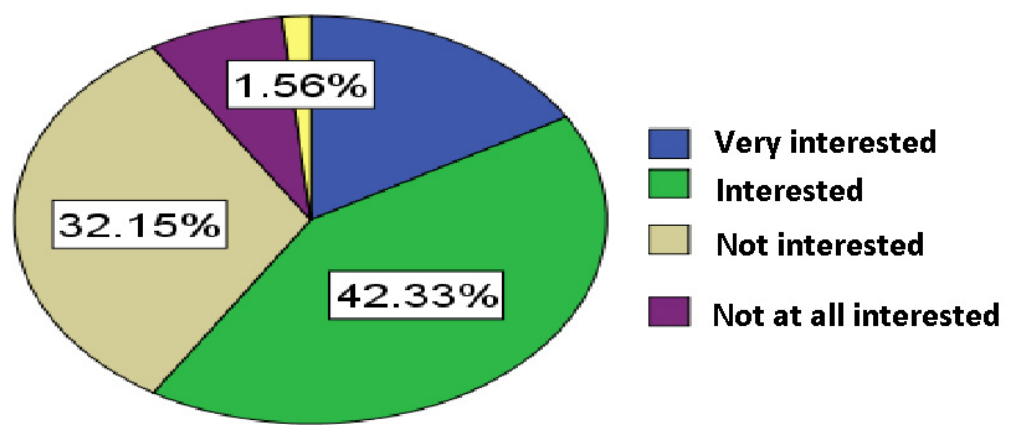

Figure 23. Lunch hour

(11) Sports

Using English while doing sports is designed to create more opportunities of English communication after the class. This activity received $57 \%$ of agreement. 


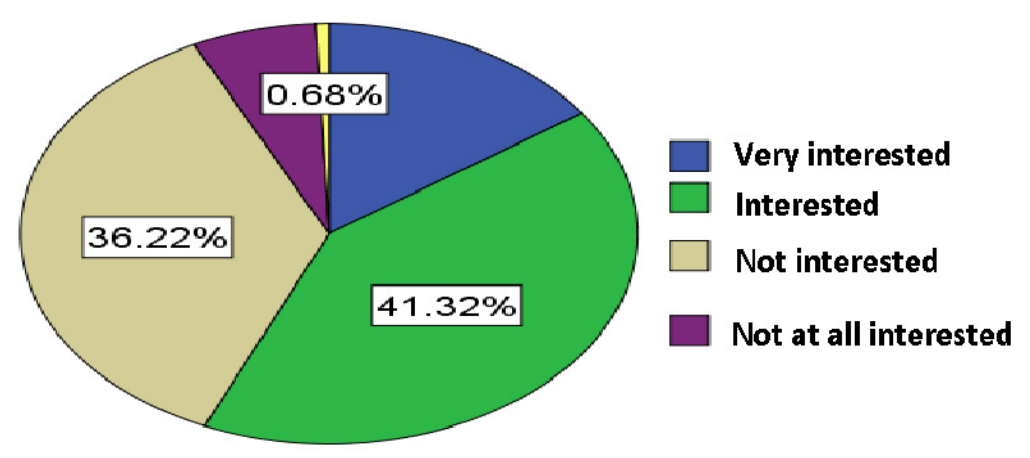

Figure 24. Sport

(12) Dramas

Dramas requires a high level of artistic aptitude and English language ability to understand and perform, so they seemed to be limited in terms of participants. This activity received an agreement rate of about $54.3 \%$.

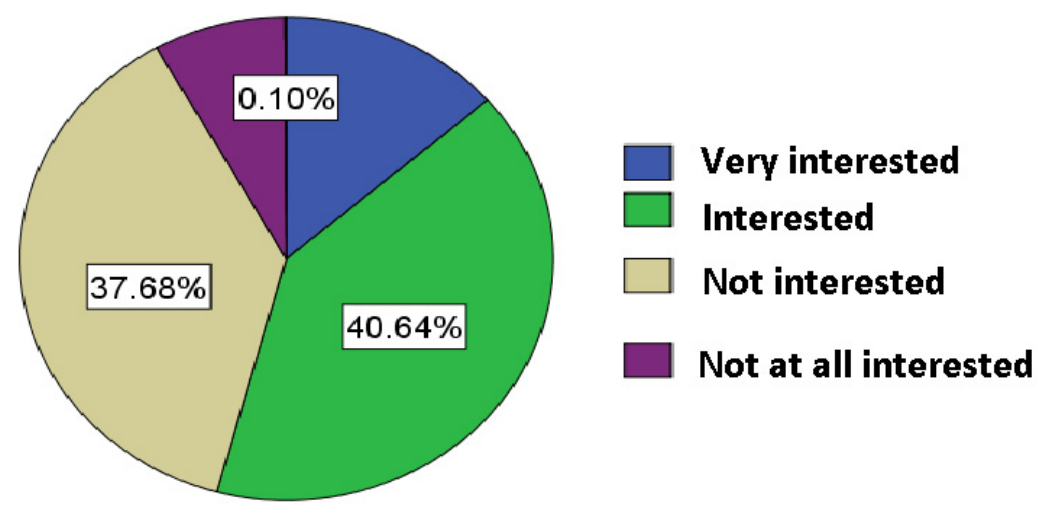

Figure 25. Drama

(13) Songs

With the difficult requirement of artistic talents, English song writing and performance had a lower agreement rate of $47.2 \%$. However, this activity has been maintained famely for over 10 years at the University of Social Sciences and Humanities, which created a strong echo through many student generations. 


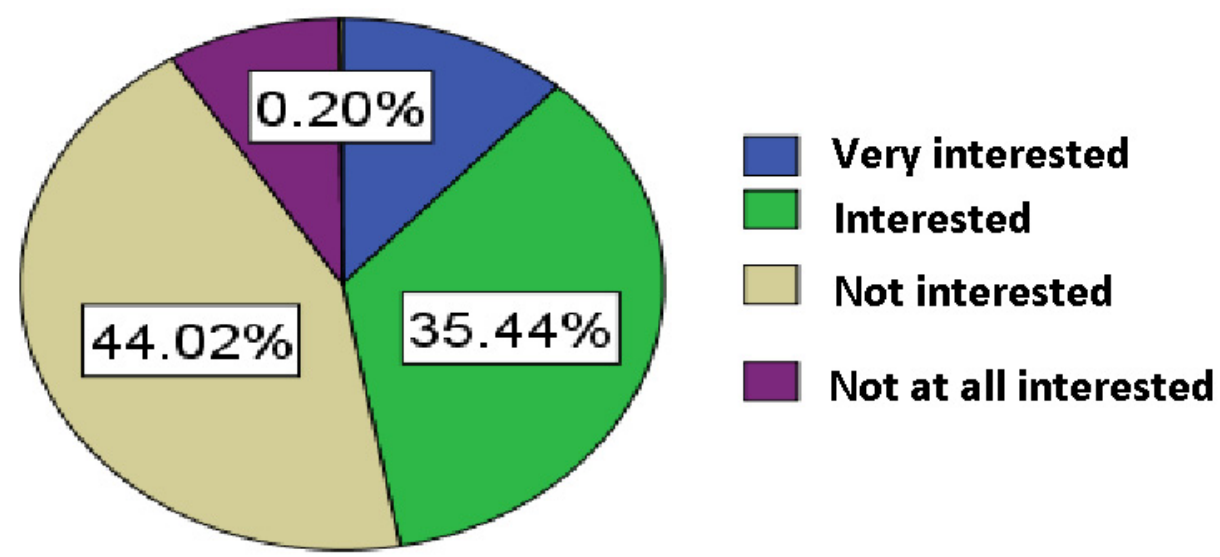

Figure 26. Song writing and performance

In addition, students have also contributed more useful ideas about extracurricular activities such as: Linking with non-governmental organizations operating in Ho Chi Minh City to introduce internships for students (Huang, Tran-Chi, Wang, \& Le, 2019); Organizing mock tests of international English examinations; Communicating English at breakfast being probably better than at lunch.

\subsection{Developing English Extra-Curricular Programs}

\subsubsection{Extracurricular Programs for Improving English for International Examination}

For the first objective, extracurricular activitites aimed at improving scores in the international English examinations should be structured in terms of comprehensive content and sufficient training duration, ensuring the effective transmission of academic English knowledge and skills, with the priority of the following forms as: short-term training, eloquence, and comentary writing. In addition, the need of standardizing English level should be encourged and supported by a long term training program at universities.

\subsubsection{Extracurricular Programs for ESP}

For the second objective, extra-curricular activitities for developing English for Special Purposes should focus on Business English and Legal English, including the following programs: exhibitions and fairs, seminars, internships, and contests. These need to be supported by local and foreign companies for finance aids and human resources.

\subsubsection{Extracurricular Programs for Developing English Communication}

For the third objective, extracurricular activities for enhancing Daily English communication can be organized intensively every day. The more opportunities for students to use communicative English in various situations, the more fluent and natural English habits they have. English extracurricular activities for improving English communication including: watching movies, listening to music, karaoke, song writing and performance, drama, 
gameshow, teambuilding, city tour, travelling, cultural festival, art performance, book coffee, lunch hour, sports.

In addition, extracurricular activities to enhance the quality of English teaching and learning should focus on entertainment elements, using modern and effective audiovisual means to attract the audience. In particular, when joining in English extracurricular activities, all the participants must apply the rule of English-only usage. In order to create an English speaking environment that is more naturally and friendly, comfortable places like Book Café should be invested effectively. At the same time, step by step enhancing English acquisition through the university's media channels such as: website, notice board, or forming voluntary English communicating with communities. Furthermore, taking advantage of empty spaces in the university campus like corridors and the main hall to set up television broadcast and lazy chairs, helping students approaching to English everywhere everytime in a natural way.

\section{Discussion}

Assessing all the three programs of extracurricular activities according to objectives showed that there was a different priority for each type of extracurricular activities. In general, the beloved activities had the ageement rate of more than $60 \%$. In specific, for English for international examination, the popular types of extracular activities were: short-term training (70\%), eloquence and conmentary writing (60\%). For English for special purposes, the activities being highly supported included: internship and exhibition fair (80\%), contests on company's activities, and conferences (70\%). For communicative English, the favourable activities with the agreement rate of over $80 \%$ included: watching movies, listening to music, going to Tây streets, traveling and speaking club; The other activities with the agreement rate of less $60-70 \%$ included: games, cultural shows, book cafe, puzzles, karaoke, lunch hour; And the rest activities which are assessed less attractive to students including sports, drama, and songwriting in English.

In short, the participants showed a high level of interest and involvement in English extracurricular activities. Extracurricular activities should aim to develop not only on ESP and communicative skills but also on language test-taking strategies. In addition, extracurricular activities need to go beyond the boundaries of classrooms, providing students with more opportunities for foreign language practice in real life and with the people from different English speaking countries. The most important factor needed to be much more concerned as organizing extracurricular activities is how to learn English with fun. Last but not least, group study for further language practice should be encouraged more at universities.

The participants showed a high level of interest and involvement in English extracurricular activities. Extracurricular activities should aim to develop not only on ESP and communicative skills but also on language test-taking strategies. In addition, extracurricular activities need to go beyond the boundaries of classrooms, providing students with more opportunities for foreign language practice in real life and with the people from different English speaking countries. The most important factor needed to be much more concerned as organizing extracurricular activities is how to learn English with fun. Last but not least, group 
study for further language practice should be encouraged more at universities.

\section{Conclusion}

From the study, there was a great demand of students to participate in English extracurricular activities with about $80 \%$ of agreement on three specific objectives consisting of improving: English for international examination, English for Special Purposes, and English for Daily communication. The objective of improving English for Daily communication occupied the most proportion.

\section{References}

Benson, P. (2011). Language learning and teaching beyond the classroom: An introduction to the field Beyond the language classroom (pp. 7-16): Springer. https://doi.org/10.1057/9780230306790

Gibson, J. J. (2014). The ecological approach to visual perception: classic edition: Psychology Press. https://doi.org/10.4324/9781315740218

Hoàng, V. V. (2008). Những yếu tố ảnh hưởng đến chất lượng đào tạo tiếng Anh không chuyên ở Đại học Quôc gia Hà Nội (Factors affecting the quality of English education at Vietnam National University, Hanoi). VNU Journal of Foreign Studies, 24(1), 22-37.

Holland, A., \& Andre, T. (1987). Participation in extracurricular activities in secondary school: What is known, what needs to be known? Review of Educational Research, 57(4), 437-466. https://doi.org/10.3102/00346543057004437

Huang, S.-T. T., Tran-Chi, V.-L., Wang, F.B., \& Le, V.Q. (2019). A Structural Equation Modeling Analysis on Practicum Satisfaction of the Vietnamese Business Students. The Journal of Social Sciences Research, 5(1), 172-182. https://doi.org/10.32861/jssr.51.172.182

Lamb, M. (2007). The impact of school on EFL learning motivation: An Indonesian case study. Tesol Quarterly, 41(4), 757-780. https://doi.org/10.1002/j.1545-7249.2007.tb00102.x

Marsh, H., \& Kleitman, S. (2002). Extracurricular school activities: The good, the bad, and the nonlinear. Harvard Educational Review, 72(4), 464-515. https://doi.org/10.17763/ haer.72.4.051388703v7v7736

Menezes, V. (2011). Affordances for language learning beyond the classroom Beyond the language classroom (pp. 59-71): Springer. https://doi.org/10.1057/9780230306790_6

Phạm, A., \& Nguyễn, H. (2012). Tiếng Anh, đã học nhưng không dùng được! (English, learned but can't be used!), Pháp Luật TP.HCM. Retrieved from https://baomoi.com/tieng-anh-hoc-xong-khong-dung-duoc/c/8369618.epi

Richards, J. C. (2015). The changing face of language learning: Learning beyond the classroom. RELC Journal, 46(1), 5-22. https://doi.org/10.1177/0033688206063470

Vũ, T. P. A. (2007). Đào tạo tiếng Anh bậc đại học: 4 cái thiếu (English training at university level: 4 shortages), Tuổi Trẻ. $\quad$ Retrieved from 


\section{Macrothink

https://tuoitre.vn/dao-tao-tieng-anh-bac-dai-hoc-4-cai-thieu-224381.htm

\section{Copyright Disclaimer}

Copyright reserved by the author(s).

This article is an open-access article distributed under the terms and conditions of the Creative Commons Attribution license (http://creativecommons.org/licenses/by/3.0/). 